\title{
PENGARUH PRAKTIK KERJA INDUSTRI TERHADAP KEMAMPUAN PENGUASAAN HARDSKILL SISWA KELAS XI PROGRAM KEAHLIAN TEKNIK KOMPUTER DAN JARINGAN SMK NEGERI 5 JEMBER TAHUN AJARAN 2016/2017
}

\author{
Nur Aulya Rizki ${ }^{1}$, Bambang Suyadi ${ }^{1}$, Retna Ngesti Sedyati ${ }^{1}$ \\ ${ }^{1}$ Program Studi Pendidikan, Fakultas Keguruan dan Ilmu Pendidikan, Universitas Jember \\ e-mail: suyadibambang219@gmail.com
}

\begin{abstract}
Abstrak
Penelitian ini dilakukan untuk mengetahui adanya pengaruh yang signifikan antara pengaruh praktik kerja industri terhadap kemampuan penguasaan hardskill siswa kelas XI Program Keahlian Teknik Komputer dan Jaringan SMK Negeri 5 Jember Tahun Ajaran 2016/2017. Metode penentuan lokasi penelitian menggunakan metode purposive area yaitu di SMK Negeri 5 Jember yang terletak di Jalan Brawijaya No. 55, Jember. Penentuan responden dalam penelitian ini menggunakan metode populasi yaitu sebanyak 69 responden. Metode pengumpulan data yang digunakan terdiri dari metode: angket, wawancara, dokumen daan observasi. Analisis data yang digunakan adalah analisis inferensial yaitu terdiri dari analisis regresi linier sederhana dan uji F. Hasil penelitian menunjukkan bahwa analisis regresi linier sederhana menghasilkan persamaan $\hat{Y}=1,965$ + 0,563X + ei dengan nilai Rsquare sebesar 0,723, hasil uji F membandingkan antara Fhitung dengan Ftabel dengan nilai Fhitung sebesar 174,447, Ftabel sebesar 3,984 pada taraf signifikansi 0,05 dengan kriteria pengujian yaitu Fhitung $>$ Ftabel maka Ho ditolak, dan jika sig $<\alpha$, maka Ho ditolak. Hal tersebut menunjukkan bahwa praktik kerja industri memiliki pengaruh yang signifikan terhadap kemampuan penguasaan hardskill siswa kelas XI Program Keahlian Teknik Komputer dan Jaringan SMK Negeri 5 Jember Tahun Ajaran 2016/2017 dengan besaran pengaruh sebesar 72,3\%, sedangkan sisanya yaitu 27,7\% dipengaruhi variabel bebas lain yang tidak diteliti dalam penelitian ini meliputi program Project Work, pendidikan informal, prestasi belajar kewirausahaan, dan penguasaan mata diklat produktif.
\end{abstract}

Kata Kunci: Praktik kerja industri, hardskill siswa

\section{PENDAHULUAN}

Perkembangan ilmu pengetahuan dan teknologi serta tuntutan globalisasi mengakibatkan persaingan yang sangat ketat dalam penyediaan sumber daya manusia yang unggul. Untuk mempertahankan daya saing, sumber daya manusia dituntut untuk terus meningkatkan kompetensi keahlian, pengetahuan dan keterampilannya. Sehubungan dengan hal tersebut, salah satu langkah untuk mempersiapkan sumber daya manusia yang berkualitas adalah dengan proses pendidikan. Dengan kata lain dapat dikatakan penidikan memegang peranan penting untuk meningkatkan kualitas sumber daya manusia.

Pendidikan menengah kejuruan merupakan salah satu macam jenis pendidikan yang diterapkan di Indonesia. Sekolah Menengah Kejuruan merupakan sub sistem pendidikan nasional yang mengutamakan mempersiapkan peserta didik untuk mampu memilih karir, memasuki lapangan kerja, berkompetisi, dan mengembangkan dirinya dengan sukses di lapangan kerja. Salah satu upaya untuk meningkatkan mutu dan relevansi pendidikan kejuruan adalah peningkatan keterkaitan dan keterpadu an (link and match) dalam implementasi Pendidikan Sistem Ganda (PSG) yang merupakan kebijaksanaan Departemen Pendidikan Nasional. Pendidikan sistem ganda merupakan penyelenggaraan pendidikan kejuruan yang mengintegrasikan secara tersisitem kegiatan pendidikan di sekolah dengan kegiatan pendidikan (praktik) di dunia usaha atau dunia industri. Undang-Undang Prakerin Dikmendikti (2003) mengungkapkan bahwa Praktik Kerja Industri (Prakerin) adalah program wajib yang harus dilaksanakan oleh sekolah khususnya sekolah menengah kejuruan dan pendidikan luar sekolah serta 
wajib diikuti oleh siswa/warga belajar. Penyelenggaraan prakerin akan membantu peserta didik untuk memantapkan hasil belajar yang diperoleh di sekolah serta membekali siswa dengan pengalaman nyata sesuai dengan program studi yang dipilihnya.

Menurut Siswanto Sastrohadiwiryo (2003: 215) menjelaskan bahwa Praktik Kerja Industri adalah suatu pelatihan di tempat kerja yang dimaksudkan untuk memberikan petunjuk khusus kepada pekerja guna melaksanakan tugas dan pekerjaannya, dimana penyelenggaraannya latihan langsung di tempat kerja, dan berupa pelatihan praktik pada situasi kerja sebenarnya. Sedangkan menurut Oemar Hamalik (2005: 91) berpendapat bahwa Praktek Kerja Lapangan merupakan suatu program latihan yang diselenggarakan di lapangan atau di luar kelas, dalam rangkaian kegiatan pembelajaran sebagai bagian integral program keahlian. Para peserta dapat memadukan antara teori proses yang telah diperolehnya di kelas dengan pengalaman praktis. Secara langsung peserta akan bertindak dan berperan sebagai tenaga kerja dalam lingkungan organisasi.. Jadi praktik kerja industri adalah suatu program pelatihan pendidikan keahlian kejuruan yang diselenggarakan di lapangan atau di luar kelas dengan cara memadukan antara pembelajaran di sekolah dengan pembelajaran di dunia usaha atau dunia industri berupa pelatihan kerja pada situasi kerja sebenarnya. Dimana indikator praktik kerja industri dalam penelitian ini meliputi jumlah jam kerja praktik kerja industri siswa dan nlai kinerja praktik siswa.

Fokus pembelajaran siswa pada saat melaksanakan praktik industri ditekankan pada penguasaan pengetahuan, keterampilan, sikap dan nilai-nilai yang dibutuhkan oleh industri. Lebih jauh lagi siswa dapat mendalami dan menghayati hasil pembelajaran di dunia kerja secara nyata sehingga dapat memantapkan keterampilan atau kemampuan teknis dalam diri mereka. Kemampuan hardskill adalah hal nyata yang terlihat dalam diri siswa. Bagi lulusan SMK dituntuk untuk menguasai keterampilan teknis (hardskill). Menurut Utomo (2010: 74) Kemampuan Hard skill didefinisikan sebagai penguasaan ilmu pengetahuan, teknologi dan keterampilan teknis yang berhubungan dengan bidang ilmu tertentu. Hard skill berhubungan dengan technical skill yang diterapkan dalam dua hal yaitu: (a) pure technical knowledge atau functional skill; (b) skill to improve the efficiency of technology, that is, improvement skill or problem-solving skill (Suharjono dalam Utomo, 2010:74). Kemampuan hardskill bisa disebut juga dengan keterampilan teknis yang melekat atau dibutuhkan untuk profesi tertentu.

Program Praktik Kerja Industri diselenggarakan di seluruh jenjang SMK di Indonesia. Hal ini sejalan dengan upaya yang dilakukan oleh SMK Negeri 5 Jember melalui Praktik Kerja Lapangan (PKL) yang merupakan implementasi Pendidikan Sistem Ganda. Lokasi dalam penelitian ini adalah SMK Negeri 5 Jember di Kabupaten Jember. Berdasarkan observasi di SMK Negeri 5 Jember bahwa proses pelaksanaan praktik kerja industri yang dilakukan oleh siswa di dunia usaha/dunia industri sangat disesuaikan dengan masing-masing program keahlian siswa dengan maksud untuk mengembangkan potensi siswa menjadi kemampuan yang semakin lama semakin meningkat dalam sikap, pengetahuan, dan keterampilan teknis diri mereka. Siswa-siswi SMK Negeri 5 Jember melaksanakan Praktik Kerja Industri selama kurang lebih 3 bulan di DU/DI sesuai dengan bidang keahliannya masing-masing, begitu juga dengan siswa-siswi kelas XI Teknik Komputer dan Jaringan. Praktik Kerja Industri merupakan kegiatan yang dilakukan di sekolah dan DU/DI berupa pendidikan, pelatihan dan pembelajaran dalam upaya pendekatan ataupun meningkatkan keterampilan teknis dan kompetensi siswa sesuai dengan bidang keahliannya. Hal tersebut sesuai dengan pendapat Longworth (2003: 79) pembelajaran bisa dilakukan dari pengalaman di industri yang berpengaruh pada manajemen diri, memperoleh pengetahuan yang baru dari praktik, manajemen keterampilan berkomunikasi, berfikir kreatif, kerjasama, fleksibilitas, adaptasi, serta lifelong learning.

Mengacu pada tujuan dari adanya prakerin yaitu menyiapkan siswa mampu memilih karir, berkompetensi, mengembangan diri, memperluas dan memantapkan kemampuan kahlian/ kompetensi 
maka diharapkan prakerin mampu meningkatkan keterampilan siswa. Tujuan praktik kerja industri menurut Depdiknas (2008) adalah sebagai pemenuhan kompetensi sesuai tuntutan kurikulum, implementasi kompetensi ke dalam dunia kerja, dan penumbuhan etos kerja. Program praktek kerja bertujuan mengembangkan kemampuan profesional aspek keterampilan manajemen sesuai dengan tujuan program program pelatihan yang hendak dicapai (Oemar Hamalik, 2005:92). Berdasarkan latar belakang di atas maka permasalahan dalam penelitian ini yaitu, apakah terdapat pengaruh yang signifikan antara praktik kerja industri terhadap kemampuan penguasaan hardskill siswa kelas XI Program Keahlian Teknik Komputer dan Jaringan SMK Negeri 5 Jember Tahun Ajaran 2016/2017.

Goldstein dan Gressner (dalam Kamil, 2010:6) memberikan definisi pelatihan yang ditekankan pada tempat dilaksanakannya pelatihan. Mereka mendefinisikan pelatihan sebagai usaha sistematis untuk menguasai keterampilan, peraturan, konsep ataupun cara berperilaku yang berdampak pada peningkatan kinerja. Definisi ini memperjelas bahwa pelatihan setidaknya terkait dengan perilaku setidaknya dalam menghadapi tugas. Konsep pelatihan juga diungkapkan oleh Dearden (dalam Kamil, 2010:7), yang menyatakan bahwa pelatihan pada dasarnya meliputi proses belajar mengajar dan latihan bertujuan untuk mencapai tingkat kompetensi tertentu atau efisiensi kerja.

Kamil (2010:72) menyatakan bahwa warga belajar (pemagang) bukan hanya melihat atau mendengar teori pekerjaan, akan tetapi harus melakukan secara langsung apa yang dilihat dan dipahaminya. Melalui proses belajar seperti ini secara tidak sadar warga belajar (pemagang) selain memperoleh keterampilan, juga akan mengalami perubahan dalam pengetahuan, keterampilan dan sikap dalam menghadapi pekerjaan tersebut.

Berdasarkan uraian diatas maka dapat dikatakan bahwa pelatihan magang atau praktik kerja industri berpengaruh terhadap peningkatan kemampuan dan keterampilan peserta didik sesuai dengan kompetensi bidang keahliannya masing-masing. Dengan adanya pelatihan magang atau praktik kerja industri diharapkan mampu mengembangkan kompetensi atau keterampilan hard skill yang sudah dimiliki oleh peserta didik. Hal ini dikuatkan oleh pendapat yang dikemukakan Kaplan (dalam Kamil, 2010:72) bahwa pelibatan peserta belajar (warga belajar) dalam segala gerak proses pembelajaran akan membantu mempercepat penguatan bagi terjadinya perubahan atas diri mereka juga atas dasar kemauan diri mereka serta membantu perkembangan di masa yang akan datang.

Berdasarkan penjelasan tersebut, maka hipotesis dari penelitian ini adalah: ada pengaruh yang signifikan praktik kerja industri terhadap kemampuan penguasaan hardskill siswa kelas XI Teknik Komputer dan Jaringan SMK Negeri 5 Jember tahun ajaran 2016/2017.

\section{METODE}

Penelitian ini merupakan penelitian kuantitatif. Metode penentuan lokasi penelitian menggunakan metode purposive area yaitu di SMK Negeri 5 Jember yang terletak di Jalan Brawijaya No. 55, Jember. Jumlah responden dalam penelitian ini yaitu sebanyak 69 responden. Metode pengumpulan data dalam penelitian ini menggunakan metode angket untuk mendapatkan data tentang frekuensi jumlah jam kerja praktik siswa per hari dan nilai kinerja siswa, metode wawancara digunakan untuk mendapatan keterangan lebih lanjut tentang pengaruh praktik kerja industri terhadap kemampuan penguasaan hardskill siswa, metode dokumen digunakan untuk memperoleh data nilai kinerja dan nilai prakeri aspek teknis siswa dan metode observasi digunakan untuk mengetahui kegiatan praktik siswa di DU/DI. Sedangkan untuk metode pengolahan data menggunaka editing, skoring dan tabulasi. Analisis data yang digunakan dalam penelitian ini yaitu analisis regresi linier sederhana dan analisis varian garis regresi yaitu untuk mengetahui kuat tidaknya atau tingkat keeratan variabel praktik kerja industri terhadap kemampuan penguasaan hardskill siswa kelas XI Teknik Komputer dan Jaringan SMK Negeri 5 Jember tahun ajaran 2016/2017. Sedangkan uji F yaitu untuk mengetahui pengaruh yang 
signifikan variabel praktik kerja industri terhadap kemampuan penguasaan hardskill siswa kelas XI Teknik Komputer dan Jaringan SMK Negeri 5 Jember tahun ajaran 2016/2017. Uji efektivitas garis regresi yaitu untuk mengetahui berapa besar (\%) pengaruh variabel praktik kerja indsutri terhadap kemampuan penguasaan hardskill siswa kelas XI Teknik Komputer dan Jaringan SMK Negeri 5 Jember tahun ajaran 2016/2017.

\section{HASIL DAN PEMBAHASAN}

Hasil penelitian ini yaitu meliputi data pendukung dan data utama yang meliputi analisis inferensial. Analisis inferensial digunakan untuk menjawab rumusan masalah yaitu untuk mengetahui pengaruh yang signifikan praktik kerja indsutri terhadap kemampuan penguasaan hardskill siswa kelas XI Teknik Komputer dan Jaringan SMK Negeri 5 Jember tahun ajaran 2016/2017. Berdasarkan analisis data yang dilakukan diperoleh hasil dalam tabel berikut ini:

Tabel Ringkasan Uji F, Multiple R, dan R Square

\begin{tabular}{|c|c|c|c|c|c|c|c|c|c|c|}
\hline & \multirow[t]{2}{*}{ Variabel } & \multicolumn{2}{|c|}{$\mathrm{F}_{\text {Hitu }}$} & \multicolumn{2}{|c|}{ Sig } & \multirow{2}{*}{\multicolumn{2}{|c|}{$a$}} & \multirow[t]{2}{*}{$\mathrm{R}$} & \multirow{2}{*}{\multicolumn{2}{|c|}{ Sauare }} \\
\hline & & $\mathrm{ng}$ & Tabel &. $\mathrm{F}$ & & & & & Square & \\
\hline & $\mathrm{X}$ terhadap & & & & & 0 & & 0 & & 0 \\
\hline Y & & 447 & ,984 & 00 &, 05 & &, $850^{\mathrm{a}}$ & &, 723 & \\
\hline
\end{tabular}

Sumber : Data diolah 2017

Tabel di atas menunjukkan bahwa $\mathrm{F}_{\text {hitung }}=174,447>\mathrm{F}_{\text {tabel }}=3,984$ dengan tingkat signifikansi $\mathrm{F}=0,000<a=0,05$. Hal ini menunjukkan bahwa variabel praktik kerja industri memiliki pengaruh yang signifikan terhadap kemampuan penguasaan hardskill siswa kelas XI Teknik Komputer dan Jaringan SMK Negeri 5 Jember tahun ajaran 2016/2017. Berdasarkan data tersebut disimpulkan bahwa Ho ditolak dan Ha diterima yaitu 'ada pengaruh yang signifikan terhadap kemampuan penguasaan hardskill siswa kelas XI Teknik Komputer dan Jaringan SMK Negeri 5 Jember tahun ajaran 2016/2017'. Untuk koefisien determinasi $R_{\text {Square }}$ sebesar 0,723, yang dengan proporsi sumbangan variabel X terhadap Y sebesar $72,3 \%$, sedangkan sisanya yaitu $27,7 \%$ dipengaruhi variabel bebas lainnya yang tidak diteliti dalam penelitian ini meliputi Project Work, pendidikan informal, prestasi belajar kewirausahaan, dan penguasaan mata diklat produktif. Hubungan praktik kerja industri terhadap kemampuan penguasaan hardskill siswa kelas XI Teknik Komputer dan Jaringan SMK Negeri 5 Jember tahun ajaran 2016/2017. dapat diketahui dari multiple $\mathrm{R}$ sebesar 0,850 dengan kategori hubungan yang sangat kuat.

Pembahasan

Penelitian ini dilakukan untuk mengetahui pengaruh yang signifikan variabel praktik kerja industri terhadap kemampuan penguasaan hardskill siswa kelas XI Teknik Komputer dan Jaringan SMK Negeri 5 Jember tahun ajaran 2016/2017.Hipotesis yang menyatakan bahwa ada pengaruh yang signifikan variabel praktik kerja industri (X) terhadap kemampuan penguasaan hardskill (Y) siswa kelas XI Teknik Komputer dan Jaringan SMK Negeri 5 Jember tahun ajaran 2016/2017 diterima atau mempunyai pengaruh positif yang signifikan terhadap proses keputusan pembelian. Hal ini artinya hipotesis tersebut terjawab praktik kerja industri berpengaruh terhadap kemampuan penguasaan hardskill sebesar 72,3\%.

Dimana praktik kerja industri meliputi jumlah jam kerja praktik industri siswa dan nilai kinerja praktik siswa. Dalam Undang-Undang Ketenagakerjaan diatur 2 macam pola dan ketentuan waktu kerja (normal) yang bersifat umum sebagaimana diatu dalam Pasal 77 UUK, yaitu : 
1. Pola 6:1, yaitu hari kerja dan 1 hari istirahat mingguan, masing-masing 7 jam perhari dan maksimum 40 jam perminggu; atau

2. Pola 5:2, yaitu 5 hari kerja dan 2 hari istirahat mingguan, masing-masing 8 jam perhari dan 40 jam perminggu;

Disamping itu, juga diatur pola dan ketentuan waktu kerja yang bersifat khusus berdasarkan sektor atau sub-sektor usaha atau pekerjaan tertentu dengan suatu peraturan menteri tersendiri berdasarkan suatu periode kerja yang bervariasi sesuai karakteristiknya masing-masing. Ketentuan waktu kerja tersebut, tidak termasuk waktu istirahat antar jam kerja selama sekurang-kurangnya 30 (tiga puluh) menit, yang diberikan setelah bekerja maksimal 4 (empat) jam secara terus menerus. Berdasarkan penelitian yang telah dilakukan, dapat diketahui bahwa jumlah jam kerja praktik kerja industri siswa yang ditunjukkan oleh frekuensi jam kerja praktik siswa per hari yaitu jumlah jam kerja praktik dikalikan hari kerja.

Penilaian kinerja siswa menurut Mathis dan Jackson (2002:81) berpendapat bahwa penilaian kinerja adalah sistem formal untuk memeriksa atau mengkaji dan mengevaluasi secara berkala kinerja seseorang. Kinerja dapat pula dipandang sebagai perpaduan dari hasil kerja (apa yang harus dicapai seseorang) dan kompetensi kerja (bagaimana seseorang mencapainya). Adapun bentuk dari penilaian kinerja siswa ini diambil dari nilai kinerja siswa yang didapat setelah berlangsungnya pelaksanaan praktik kerja industri.

Variabel praktik kerja industri dengan indikator jumlah jam kerja praktik kerja industri siswa dan nilai kinerja signifikan memberikan pengaruh signifikan terhadap variabel kemampuan penguasaan hardskill siswa (Y). Berikut merupakan hasil wawancara yang dilakukan oleh peneliti dengan salah satu siswa kelas XI Teknik Komputer dan Jaringan SMK Negeri 5 Jember yang menjadi responden dalam penelitian ini.

“...................Dengan adanya praktik kerja industri tersebut dapat meningkatkan kemampuan penguasaan hardskill. Karena pada kegiatan prakerin tersebut saya dapat menggunakan peralatan secara langsung sehingga dapat meningkatkan kemampuan hardskill saya. Selain itu, dengan adanya prakerin tersebut daya memperoleh tambahan pengalaman dan keterampilan terutama yang berkaitan dengan printer, sehingga kemampuan hardskill saya mengalami peningkatan." (SN, 16 $\left.6^{\mathrm{Th}}\right)$.

Dari penjelasan tersebut, dapat diketahui bahwa dengan adanya praktik kerja industri dapat meningkatkan kemampuan penguasaan hardskill siswa kelas XI Teknik Komputer dan Jaringan SMK Negeri 5 Jember. Hal ini dikarenakan dengan adanya praktik kerja industri, maka siswa dapat memperoleh pengalaman latihan kerja secara nyata di DU/DI, sehingga dapat mempengaruhi kemampuan penguasaan hardskill siswa. Dimana kemampuan penguasaan hardskill untuk siswa kelas XI Teknik Komputer dan Jaringan tersebut dapat berupa keterampilan teknis yang didapatkan selama pelaksanaan praktik kerja industri.

Dengan adanya prakerin, kemampuan penguasaan hardskill siswa telah menunjukkan bahwa kepemilikan keterampilan teknis yang sangat berkembang ditunjukkan dengan nilai aspek teknis yang didapat oleh siswa. Hal ini selaras dengan pendapat Goldstein dan Gressner (dalam Kamil, 2010:6) memberikan definisi pelatihan yang ditekankan pada tempat dilaksanakannya pelatihan. Mereka mendefinisikan pelatihan sebagai usaha sistematis untuk menguasai keterampilan, peraturan, konsep ataupun cara berperilaku yang berdampak pada peningkatan kinerja. Definisi ini memperjelas bahwa pelatihan setidaknya terkait dengan perilaku setidaknya dalam menghadapi tugas. Konsep pelatihan juga diungkapkan oleh Dearden (dalam Kamil, 2010:7), yang menyatakan bahwa pelatihan pada dasarnya meliputi proses belajar mengajar dan latihan bertujuan untuk mencapai tingkat kompetensi 
tertentu atau efisiensi kerja.

Hal tersebut sesuai dengan pendapat guru pembimbing prakerin siswa jurusan teknik komputer dan jaringan SMK Negeri 5 Jember yang menjadi informan dalam penelitian ini.

“........................Prakerin sangat banyak memberi manfaat mbak. Yang pertama yaitu anakanak langsung terjun ke dunia kerja, sehingga bagaimana berinteraksi ke dunia kerja sudah di dapatkan dan kemampuan dalam praktek disekolah dapat langsung dipraktekan dalam Prakerin tersebut mbak. Oleh karena itulah prakerin dapat meningkatkan kemampuan hardskill siswa karena dalam Prekerin tersebut siswa dapat menggunakan segala peralatan dan fasilitas secara langsung pada lokasi prakerin, sehingga kemampuan hardskill siswa dapat meningkat" (DP, $29^{\mathrm{Th}}$ ).

Berdasarkan penelitian yang dilakukan tersebut nampak jelas bahwa pelatihan magang atau praktik kerja industri berpengaruh terhadap peningkatan kemampuan dan keterampilan peserta didik sesuai dengan kompetensi bidang keahliannya masing-masing. Dengan adanya pelatihan magang atau praktik kerja industri diharapkan mampu mengembangkan kompetensi atau keterampilan hardskill yang sudah dimiliki oleh peserta didik. Hal ini dikuatkan oleh pendapat yang dikemukakan Kaplan (dalam Kamil, 2010:72) bahwa pelibatan peserta belajar (warga belajar) dalam segala gerak proses pembelajaran akan membantu mempercepat penguatan bagi terjadinya perubahan atas diri mereka juga atas dasar kemauan diri mereka serta membantu perkembangan di masa yang akan datang.

Pelaksanaan prakerin sangat tergantung pada ketersediaan perangkat sekolah yang berkaitan dengan prakerin. Pada dasarnya prakerin identik dengan pendidikan dan latihan, maka keberhasilan pelaksanaan prakerin dari adanya kerjasama sekolah dengan dunia kerja. Kamil (2010:72) menyatakan bahwa warga belajar (pemagang) bukan hanya melihat atau mendengar teori pekerjaan, akan tetapi harus melakukan secara langsung apa yang dilihat dan dipahaminya. Melalui proses belajar seperti ini secara tidak sadar warga belajar (pemagang) selain memperoleh keterampilan, juga akan mengalami perubahan dalam pengetahuan, keterampilan dan sikap dalam menghadapi pekerjaan tersebut.

Berdasarkan penjelasan tersebut, maka hipotesis dalam penelitian ini dapat diterima yaitu ada pengaruh yang praktek kerja industri terhadap kemampuan penguasaan hardskill siswa kelas XI Teknik Komputer dan Jaringan SMK Negeri 5 Jember tahun ajaran 2016/2017. Hal ini dikarenakan prakerin yang dilaksanakan SMK Negeri 5 Jember dapat mendorong siswa kelas XI Teknik Komputer dan Jaringan mengaplikasikan segala ilmu yang dipeorleh di sekolah pada saat prakerin. Hal ini sesuai dengan pendapat Longworth (2003: 79) yang menjelaskan bahwa pembelajaran bisa dilakukan dari pengalaman di industri yang berpengaruh pada manajemen diri, memperoleh pengetahuan yang baru dari praktik, manajemen keterampilan berkomunikasi, berfikir kreatif, kerjasama, fleksibilitas, adaptasi, serta lifelong learning.

\section{PENUTUP}

Berdasarkan hasil penelitian dan pembahasan myang telah dilakukan maka dapat diambil kesimpulan bahwa praktik kerja industri memiliki pengaruh yang signifikan terhadap kemampuan penguasaan hardskill siswa kelas XI Teknik Komputer dan Jaringan SMK Negeri 5 Jember tahun ajaran 2016/2017. Keterampilan teknis siswa meningkat ketika dipengaruhi oleh kegiatan praktik kerja industri yang dilakukan oleh siswa.

Berdasarkan kesimpulan di atas dari penelitian ini, maka peneliti ingin memberikan saran yaitu bagi pihak sekolah, hendaknya meningkatkan kerjasama dengan dihak Du/Di yang relevan dengan program keahlian teknik komputer dan jaringan untuk dijadikan sebagai tempat Prakerin. Hal ini dimaksudkan agar memberikan pengalaman baru bagi siswa serta masukan tambahan bagi sekolah. 
Bagi siswa, hendaknya lebih bersungguh-sungguh dalam menyelesaikan segala tugas yang diberikan dari pihak Du/Di dan pihak sekolah pada pelaksanaan Prakerin tersebut serta meningkatkan kreativitas. Dan bagi peneliti lain, untuk ikut mempertimbangkan sumbangan pengaruh variabel bebas lain yang tidak diteliti dalam penelitian ini. Oleh karena itu diharapkan bagi peneliti lain yang akan melakukan penelitian serupa dengan penelitian ini untuk mengambil variabel lain yang tidak turut diteliti dalam penelitian ini.

\section{DAFTAR BACAAN}

Dikmendikti. 2003. Undang-Undang 2003. http://kal.dikmendikti.go.id/download/SK_PKAL.doc. [Diakses pada tanggal 2 Januari 2017].

Hamalik, Oemar. 2005. Manajemen Pelatihan Ketenagakerjaan Pendekatan Terpadu Pengembangan Sumber Daya Manusia. Jakarta: PT Bumi Aksara.

Kamil, Mustofa. 2010. Model Pendidikan dan Pelatihan. Bandung: Alfabeta.

Longworth, Norman. 2005. Lifelong Learning in Action. USA: Kogan Page.

Mathis, dan Jackson. 2002. Manajemen Sumber Daya Manusia. Edisi pertama,. Cetakan Pertama. Yogyakarta: Salemba Empat.

Munandar, Ashar Sunyoto. 2008. Psikologi Industri dan Organisasi. Jakarta: Universitas Indonesia (UI-Press).

Sastrohadiwiryo, Siswanto. 2003. Manajemen Tenaga Kerja Indonesia Pendekatan Administratif dan Operasional. Jakarta: Bumi Aksara.

Undang-Undang Republik Indonesia Nomor 13 Tahun 2003. Ketenagakerjaan. 25 Maret 2003. Lembaran Negara Republik Indonesia Tahun 2003 Nomor 4279. Jakarta. 